\title{
Does Auditor Industry Expertise Improve Audit Quality In Complex Business Environments?
}

\author{
Sansaloni Butar-Butar ${ }^{1^{*}}$ and Stefani Lily Indarto ${ }^{1}$ \\ ${ }^{1}$ Faculty of Economics and Business, Soegijapranata Catholic University of Semarang \\ Л. Pawiyatan Luhur IV/1 Bendan Dhuwur, Semarang 50234, INDONESIA \\ Email: sansaloni@unika.ac.id
}

\begin{abstract}
This study examines the role of specialist auditors in enhancing the quality of financial statements by taking into account industry complexity. The test of hypotheses are conducted in two steps. The first step is to provide evidence that earnings quality, measured by earnings persistent, of firms operating in the complex and non-complex industry are different. The second step is to compare the absolute abnormal accruals of companies engaged in the complex industry with those from non-complex industry audited by non-specialist and specialists auditors. Results show: 1) earnings persistence of firms in complex industries are lower than those in non-complex industries. 2) absolute abnormal accruals of firms operating in complex industries are higher than those in non-complex industries regardless industry specialization. Overall, the results suggest that auditor industry expertise does not play a significant role in improving the quality of audited earnings in complex business environment.
\end{abstract}

Keywords: Specialist auditor; earnings persistence; industry complexity; financial reports.

\section{INTRODUCTION}

Firm business environment may affect the reliability of financial statements to reflect firm economic reality. A sophisticated business environment creates uncertainty causing accountants to face difficulties in assessing the impact of events and transactions on company's resources. The situation may lead to inappropriate accounting policy choices and ultimately hinder financial statements users in making effective business decisions. Bushman et al. [1] argue that firm complexity due to business and geographic line diversification decreases transparency. Firms operating in a particular industry where rapid environment changes occur very often will have high obstacles in recording business transactions. Francis and Gunn [2] supported the view stating that accounting industry complexity arises from difficulties in mapping economic activities into generally accepted accounting principles (GPPA), and accounting rules as basis for measurement of assets, liabilities, revenues, costs, and owner's equity.

Francis and Gunn [2] illustrated the accounting complexity of computer and software sectors. They stated that ordinary business practice requires firms in these industries to bundle multiple products together, such as providing after-sale services, free software updates, and assisting installation or providing assistance with software problems. Revenue recognition for the particular transactions requires firms to apply multiple deliverable accounting rules. These rules are quite complicated. Firms have to estimate selling price for each separate unit of accounting that require thorough understanding of the industry's products and services. Recognizing revenue from transactions involving different accounting rules are difficult to accomplish and might induce measurement errors. The situation might lead to low quality of audited earnings.

Bushman et al. [1] use earnings timeliness to assess the impact of firm complexity on reported earnings. They found that firm complexity measured by industrial and geographic concentrations affects earnings timeliness. Meanwhile, Doyle et al. [3] find that firms with weak internal control systems tend to engage in complex business activities and to have poor financial conditions.

Plumlee and Yohn [4] investigated factors leading to increasing restatement in the US during 2003-2006. The restatement was used as an indicator of earnings quality. They found that $37 \%$ of restament were related to the application of accounting standards. As much as 58\% of restating firms were due to uncertainty in accounting standards, and $37 \%$ were related to the use of judgment in applying accounting standards. The evidence suggests that increasing restatements in 
the US was partly because the inability of firms to correctly interpret and choose the most appropriate accounting policies in complex situation. When firms subsequently discover errors and misaplication of GAAP, restatement of finansial statements are to be made.

Prior Empirical results support the positive relationship between industry specialization and audit quality. Dunn and Mayhew [5] argued that the auditor with industry specialization improve the quality of audited earnings largely because they provide audit services that differ from other accounting firms. Industry specialist auditors can differentiate services that separate them from competitors who have no expertise in a particular industry. Previous studies on the relationship between auditor industry specialization and earnings quality reported consistent results $[6,7,8]$. Other studies had investigated the association between auditor industry expertise and audit fees and found that audit fees for specialist auditors were higher than non-specialist auditors $[9,10,11,12,13]$.

In contrast, previous studies in Indonesia examining the association between auditor industry expertise and audit quality reported mixed results. Several studies reported positive association between industry specialist auditors and audit quality $[14,15,16,17,18,19]$. Other studies found negative association [20]. Meanwhile, some studies fail to provide evidence on the association between industry expertise and audit quality [21,22,23,24,25].

The mixed results may stem from different proxies employed for audit quality, industry specializations or different samples periods. For example, Setiawan and Fitriani [14] used discretionary accruals as audit quality proxy and 10\% audit market share as a threshold for industry specializations. Herusetya [21] used earnings response coefficients as a measure of audit quality. They also employed $15 \%$ and $30 \%$ threshold to classify auditors as industry specialists. Furthermore, the mixed results may be attributable to the researcher's assumption that industry expertise is relevant to all type of industries.

This study attempts to explain the mixed results of prior auditor industry specialization studies in Indonesia. As far as authors' knowledge, no previous research has ever been conducted to explain the phenomenon. We argue that industry complexity may explain the inconsistent results of previous studies in Indonesia. Firms operating in complex industries have difficulties in applying accounting rules required by GAAP. In effect, the reported earnings of firms in complex sectors contain higher noise than those operating in less complicated areas. Unlike Francis and Gunn [2], we argue that auditor industry expertise is only relevant and to play a significant role in improving earnings quality of firms in less complicated industries. In addition this study also investigates the effect of industry complexity on non-specialist auditors. It is expected that earnings quality of firms in complex industry audited by non-specialist auditors is of lower quality than firms in noncomplex industry audited by non-specialist auditors.

\section{LITERATURE REVIEW AND HYPOTHESIS DEVELOPMENT}

\section{Accounting Industry Complexity}

Diversification of business causes significant changes to firm operational and control activities that a good corporate governance system must be established. Busman et al. [1] stated that multiindustry and multinational companies posing complex managerial environments experience monitoring and control issues. Good monitoring systems should be developed to coordinate cross-border corporate activities. Differences in geography, currency, audit costs, legal systems, language, tax systems, financial restrictions, and culture may lead to information complexities $[26,27,28]$.

The cause and consequences of diversification have become important topics and filled academic literatures. Dennis et al. [27] reported that the costs of diversification are higher than its benefits. The mounting costs are due to increased agency costs between managers and shareholders. Increased agency costs will hurt capital allocation and distract manager focus. Furthermore, the diverse corporate activities and unrelated segments lead to the emergence of organizational culture conflicts and operational styles that distract managers from more strategic tasks. Owen and Polk [29] reported evidence that diversification was negatively related to firm value. They concluded that diversification destroys company value.

In addition to the lowering corporate value, the diversification also encourages a severe information gap between parties within the company, and with outside investors [30]. Diversification causes business activities and enterprise information systems to become increasingly sophisticated [1]. Givoly et al. [31] argued that diversification makes segment reporting to be less informative. They compare firms with one business line with more than one line of businesses. They found that the measurement errors of more than one line of business segment are higher than firms with one business line. Peterson [32] examined whether accounting complexities increase the likelihood of revenue restatements. They showed that the com- 
plexity of revenue measurement increases the probability of revenue restatements. Moreover, the revenue restatements occur due to intentional and unintentional reporting errors.

\section{Auditor Industry Specialist}

Auditor knowledge of accounting are critical factors that improve audit quality. According to Danos [33], there are at least five categories of knowledges required to perform audit: general auditing, functional areas (e.g., tax and computerbased auditing), accounting issues (leasing and pensions), industry issues, and clients' businesses. The category one, two, and three can be obtained through formal education. But it is rare for a person to have all the necessary accounting and auditing knowledge in audit engagement. The category four and five are not entirely the domain of professional accountants. Knowledge of industry is particularly important when auditors are performing audits in industries that possess different or unique accounting rules. Knowledge of client businesses helps auditor to identify potential problems and communicate them with company employees.

Referring to Porter [34], Mayhew and Wilkins [35] proposed arguments to explain why specialization is required for accounting firms. In the context of Porter's competitive advantage, accounting firms should attempt to identify ways that can differentiate them from competitors by providing high-quality services that other accounting firms are difficult to mimic. By focusing on differentiation, the accounting firm creates opportunities to meet the client's unique needs. The accounting firm must provide unique services which cannot be readily imitated by competitors. The differentiation should be directed to the characteristics of clients and the type of services required, such as size, the number of segments, industry membership, regulation, and capital sources [36]. Mayhew and Wilkins [35] stated that client industry membership is the essential dimension that can be used to identify the need of clients. Industry specialization is important because it allows accounting firms to handle differentiation strategies to meet the needs of a large group of companies having the same characteristics. Industry specialization is expected to have positive impact on an accounting firm income.

Empirical studies on auditor industry specialization suggest that industry specialist auditors are paid higher than non-specialists. Craswell et al. [9] reported higher audit fees received by auditors with industry specialization in Australia's audit market on 1987. Hogan and Jeter [10] investigated the market share of accounting firms with industry specialization. They provided evidence that the degree of audit concentration had increased during 1976 to 1993. Meanwhile, Ferguson [11] documented evidence that market perceptions and appreciation for auditor industry expertise in Australia were primarily based on industry leadership at office-level and city level expertise. This is consistent with evidence in Choi et al. [12] and Reichelt and Wang [13] suggesting that audit market is dominated by city-specific markets.

\section{Earnings Quality}

Conceptual arguments and explanation concerning earnings quality have become a critical academic discussion in the accounting literature. But differences in definitions and how to measure it still exist to these days. According to Dichev et al. [37], various measurements have been proposed and used in earnings quality empirical researchers; including earnings persistence, predictability, asymmetric loss measurements, benchmark beating forms, income smoothing, magnitude of accruals, income increasing accruals, absolute abnormal accruals, and the extent to which accruals are mapped to cash flow. For auditor industry specialization, studies found that auditor industry specialists have higher earnings quality [6,7]. The findings are consistent with argument that industry-specific auditors are able to position themselves differently to produce higher audit quality [38]. High audit quality is also associated with major investments in technology, physical facilities, employees, and organizational control systems that enable industry specialist auditors to detect irregularities and misstatements more easily [39]. Their ability to produce higher audit quality derives from the accumulation of experiences they obtain from companies in the same sectors and knowledge of best practice in different sectors.

Khrisnan and Yang [40] used earnings response coefficients as a proxy for earnings quality. The results showed that the reported earnings of firms with industry specialist auditor have higher earnings response coefficient relative to nonspecialist auditors. Carcello and Nagy [41] found a negative association between industry specialist auditors and fraudulent financial statements. Balsam et al. [7] showed that the absolute abnormal accruals of firms with industry specialist auditor were smaller than those of non-industry specialists.

\section{Hypothesis Development}

Accounting complexity arises from the inherent difficulty in applying accounting standards 
and mapping firm economic activities into accounting rules as a basis for recognizing and measuring accounting elements such as assets, liabilities, revenues, costs and owner's equity [2]. The accounting complexity requires specific accounting knowledge to identify potential problems in client financial statements [33]. Business trends and jargon used in industry are often unique and solely belong to the industry.

In some industries such as the service sector, the business model is not complicated. Firms pose no difficulties to implement GAAP. In contrast, industries such as software development or construction sector with long life cycles have more complex business models. The peculiar business practices make it difficult for accountants to choose appropriate accounting treatments. Transactions in those industries are often involved cash. Therefore, the inherent difficulty in applying GAAP in complex industries should be expected to affect the quality of reported earnings. Since it has higher likelihood of estimation error and contains noise signals, earnings in the complex industries are expected to be less persistent than firms in less complicated industries. Arguments connecting industrial complexity and earnings characteristics are expressed in the following hypotheses:

H1: Earnings in complex industries are less persistent than those in non-complex industries.

A large body of research on the association of auditor industry specialization and earnings attribute $[40,7,42]$ assume that auditor industry expertise is relevant to all type of industries. In other words, industry specialist can always provide higher audit quality regardless of the type of industries firms belong. However, Francis and Gunn [2] objected the assumptions saying that non-industry specialist auditors can audit financial statements as good as specialist auditors if clients operate in non-complex industries.

Dichev et al. [37] identified various measures of earnings quality, including asymmetric loss measurements, various forms of benchmark-beating, the magnitude of accruals, income increasing accruals, absolute abnormal accruals, and the extent to which accruals are mapped into cash flows. Prior studies on the association between auditor industry expertise and earnings quality documented evidence that firms with industry specialist auditors have higher earnings quality measured by low abnormal absolute accruals $[6,7,43,3]$. However, Francis and Gunn [2] argued that industry complexity brings advantage to specialist auditors because they can exploit their industry expertise relative to non-specialist auditors.
In less complicated industries financial reporting issues are less complicated. Audit judgments in assessing and interpreting GAAP are much easier to exercise. In contrast, economic events or transactions in complex industries are difficult to measure with a high degree of certainty. This is due to estimations and assumptions that accountants have to make in relation to future events. In such situations, auditors can no longer rely on knowledge and audit skills to assess client's accounting policies but on discretion alone. The previous knowledges and experiences are less relevant when dealing with uncertain situations. Therefore it is expected that audit performance of specialist auditors vary considerably in complex industries relative to less-complex industries. As a result, the quality of audited earnings measured by absolute abnormal accruals will be decreased. In other words, absolute abnormal accruals of firms operating in complex business environments are expected to be higher relative to those operating in less complex environments. Arguments connecting absolute abnormal accruals, industry complexity and industry specialization auditors are expressed in the following alternative hypothesis:

$\mathrm{H} 2$ : Absolute abnormal accruals of firms with audit industry specialists are greater in complex industries than those in non-complex industries.

The two hypotheses above emphasize the effect of industry complexity on the ability of auditors in detecting rrors in financial statements. It is argued that the negative impact of industry complexity on audit performance will also present in clients with non-industry specialization. In fact, the effect is predicted to be greater. Without sufficient knowledge and experience of business practices in complex industrial environments, nonspecialist auditors will pose severe obstacles in performing the audit with unprecedented economic events. Accounting complexity surrounding transactions in the complex environment is so high that makes difficult for non-specialist auditors to exploit their industry specialization in determining the most appropriate accounting treatments. Incorrect estimates and improper accounting policy choices increase absolute abnormal accruals contained in audited earnings. In contrast, in less-complex industrial environments, auditing expertise of nonspecialist auditors are relevant and useful. Estimation errors and misleading accounting policies can be reduced and eliminated. As a consequence, abnormal accruals contained in audited earnings are smaller. The argument leads to the following hypothesis: 
H3: Absolute abnormal accruals of firms with nonspecialists auditorsare greater incomplex industries than those in non-complex industries.

\section{RESEARCH METHOD}

\section{Population and Sample}

The population of this study are all listed companies on the Indonesia Stock Exchange, and the samples are firms releasing complete financial statements with necessary information to measure research variables during 2012-2015. Firms belonging to the financial industry (banks, insurance, and other financial institutions) are excluded due to different characteristics of accruals. Miscellaneous industry is also excluded because it is difficult to compare it with industrial grouping proposed in Francis and Gunn [2]. Francis and Gunn [2] separated firms into complex and non-complex industries based on thorough analysis of firm dynamics environments. Data are obtained from annual report uploaded online by Indonesian Stock Exchange and can be accessed via www.bei.co.id. However, annual reports of public companies which are not available on the official website of Indonesian Stock Exchange, are collected from company's official website and other sources from the internet with the help of Google search engine. If annual reportof firms cannot be collected from all indicated sources then they are eliminated from the sample.

Table 1 presents the sampling procedure in detail. The number of firms satisfying the criteria for 2012-2015 are 130 firms samples. Thus 520 (130 x4) observations are available for further analysis.

Table 1. Sample Selection Procedure

\begin{tabular}{lr}
\hline \multicolumn{1}{c}{ Criteria } & Total \\
\hline Firms were listed on IDX in 2015 & 532 \\
Firms are consecutively listed from 2012-2015 & $(71)$ \\
Firms belong to financial, insurance, and & $(219)$ \\
miscellaneous industry is excluded. & \\
$\begin{array}{l}\text { Annual reports areavailable in Rupiah } \\
\text { Annual report canbe downloaded from data }\end{array}$ & $(20)$ \\
sources & $(92)$ \\
\hline \multicolumn{1}{c}{ Final Sample } & 130 \\
\hline
\end{tabular}

\section{Variable Measurements}

\section{Accounting Industri Complexity}

Firm samples are classified into industry groups based on Jakarta Stock Industrial Classification (JASICA). The grouping is available on IDX FACT BOOK. Based on JASICA, firms are grouped into 9 sectors: Agriculture (1), Mining (2), Basic Industry and Chemicals (3), Miscellaneous Industry (4), Consumer goods Industry (5), Property, Real Estate And Building Construction (6), Infrastructure, Utilities \& Transportation (7), Finance (8) and Trade, Service \& Investment (9).

The criteria to clasify firms into into complex and non-complex industries follow Francis and Gunn [2]. A complete list of complex and noncomplex firms based on Francis and Gunn [2] are described in the appendix. Firm samples classification under JASICA will be compared to the list of industry groups proposed in Francis and Gunn [2] to determine whether companies are in complex or less complex industrial categories. For example, under JASICA PT. Astra Argo Lestari is classified as agriculture industry. Based on Francis and Gunn [2], the agriculture industry is categorized as a complex industry. Thus, PT. Astra Argo Lestari is a firm that belongs to the complex industry. However, miscellaneous industry under JASICA is eliminated because it is difficult to determine whether the industry is categorized as a complex or non-complex industry.

\section{Earnings Persistent}

Following Sloan [44], earnings persistent is measured as coefficient regression of current year earnings on prior year earnings. Below is the model to estimate earnings persistent:

Earnings $=\alpha+\beta_{1}$ Earnings $-1+\varepsilon$

Equation (1) is estimated separately for firms operating in complex and less complex industries. Hypothesis one was then tested by comparing the regression coefficients for each industry group using a non-parametric statistical test of two samples Kolmogorov-Smirnov Z.

\section{Abnormal Accruals}

Four different models are employed to estimate abnormal accruals. However, performance matched discretionary model proposed by Kothari et al. [45] is used as a basis for accepting or rejecting the hypotheses. The model controls for the effect of firm performance on accruals and is widely used in earnings management research. While the rest of the models are used to assess the consistency of the results (robustness check). The four models are described below.

a. Kothari Model [45]

$\mathrm{ACCR}_{\mathrm{t}} / \mathrm{TA}_{\mathrm{t}-1}=\mathrm{B}_{0}+B 1\left(\Delta \mathrm{SALE}_{\mathrm{i}, t} \mathrm{TA}_{\mathrm{t}-1}\right)+\mathrm{B}_{2}$ $\left(\mathrm{PPE}_{\mathrm{t}} / \mathrm{TA}_{\mathrm{t}-1}\right)+B_{3}\left(\mathrm{ROA}_{\mathrm{t}} / \mathrm{TA}_{\mathrm{t}-1}\right)+\varepsilon_{\mathrm{i}, \mathrm{t}}$

ACCRt is the total accruals on year $t$ obtained from the difference between earnings before 
extraordinary items and discontinued operation and cash flow (CFO), TAt-1 is a prior year total asset, $\triangle \mathrm{SALE}_{\mathrm{t}}$ represents a change in sales in year $t, \mathrm{PPE}_{\mathrm{t}}$ represents equipment, plant, and property in year $t$ and $R A_{t}$ is a continuing operating income deflated by total assets. The model is estimated pool-cross-sectional for each industry. The abnormal accruals are residual from the regression model. Abnormal accruals are then transformed into an absolute value and served as a proxy for earnings quality.

b. Ball dan Shivakumar Model [46].

$\mathrm{ACCR}_{\mathrm{t}} / \mathrm{TA}_{\mathrm{t}-1}=\alpha_{1}\left(1 / \mathrm{TA}_{\mathrm{t}-1}\right)+\alpha_{2}\left(\Delta \mathrm{SALE}_{\mathrm{t}}-\Delta \mathrm{REC}_{\mathrm{t}} / \mathrm{TA}_{\mathrm{t}}\right.$ $\left.{ }_{1}\right)+\alpha_{3}\left(\mathrm{PPE}_{t} / \mathrm{TA}_{\mathrm{t}-\mathrm{1}}\right)+\alpha_{4}\left(\mathrm{CFOt} / \mathrm{TA} \mathrm{t}_{-1}\right)+\alpha_{5} \mathrm{D}_{-} \mathrm{CFO}_{\mathrm{t}}+$ $\mathrm{a}_{6}\left(\mathrm{CFOt} / \mathrm{TA}_{\mathrm{t}-1}\right) * \mathrm{D}_{-} \mathrm{CFO}_{\mathrm{t}}+\mathrm{e}_{\mathrm{t}}$

ACCR it is similar to Kothari model, CFOt is the operating cash flow for the current year, $\mathrm{TA}_{\mathrm{t}-1}$ is total asset in $\mathrm{t}-1, \Delta \mathrm{SALE}_{\mathrm{t}}$ represents the change in sales in year t, $\triangle \mathrm{REC}_{\mathrm{t}}$ is the change in receivables in year t,D_CFOt is a dummy variable, 1 if the operating cash flow is positive and 0 otherwise, and $\mathrm{PPE}_{t}$ represents equipment, plant, and property in year $t$. This model is cross-sectionaly estimated for the entire observation period.

c. Modified Jones Model [47].

$\mathrm{ACCR}_{t} / \mathrm{TA}_{\mathrm{t}-1}=\alpha_{1}\left(1 / \mathrm{TA}_{\mathrm{t}-1}\right)+\alpha_{2}\left(\Delta \mathrm{SALE}_{\mathrm{t}}-\Delta \mathrm{REC}_{/}\right.$ $\left.\mathrm{TA}_{\mathrm{t}-1}\right)+\alpha_{3}\left(\mathrm{PPE}_{t} / \mathrm{TA}_{\mathrm{t}-1}\right)+\mathrm{e}_{\mathrm{t}}$

All variables are defined and measured the same way as in Kothari Model and Ball and Shivakumar (2006).

d. Kasznik Model [48].

$\mathrm{ACCR}_{\mathrm{i}, \mathrm{t}} / \mathrm{TA}_{\mathrm{i}, \mathrm{t}-1}=\alpha_{1}\left(1 / \mathrm{TA}_{\mathrm{i}, \mathrm{t}-\mathrm{-}}\right)+\alpha_{2}\left(\Delta \mathrm{SALE}_{\mathrm{i}, t} \mathrm{TA}_{\mathrm{i}, \mathrm{t}}\right.$ 1) $+\alpha_{3}\left(\mathrm{PPE}_{\mathrm{i}, t} / \mathrm{TA}_{\mathrm{i}, \mathrm{t}-1}\right)+\alpha 4\left(\Delta \mathrm{CFO}_{\mathrm{i}, t} / \mathrm{TA}_{\mathrm{i}, \mathrm{t}-1}\right)+\mathrm{e}_{\mathrm{i}, \mathrm{t}} \quad$ (5) All variables in this model are defined and measured the same way as in Modified Jones Model, Kothari Model, and Ball and Shivakumar model.

\section{Auditor Industry Specialist}

Following Kwon et al. [42], auditor's market share is used to determine whether an accounting firm has industry expertise. Auditor market share are computed as follows:

Auditor market share $=\frac{\sum_{j=1}^{J i k} \text { Sale }_{i j k}}{\sum_{i=1}^{l k} \sum_{j=1}^{J i k} \text { Sale }_{i j k}}$

The numerator is the total sales of all clients audited by accounting firm $\mathrm{i}$ in industry $\mathrm{k}$. The denominator is the sum of the total sales of all firms in industry k. An accounting firm is considered as having industry specialization if it controls more than 20 percent of the audit market share [35].

\section{Control variables}

Five control variables are added to control the impact of firm characteristics. They are firm size (total assets), debt to asset ratio, profitability (return on asset), and operating cash flow. Control variables are included to reduce errors in variables to anticipate the effects of omission of variables.

\section{Model Specifications}

\section{Hypothesis One}

Hypothesis one predicts that earnings persistence of firms in complex industries are lower than those in less complex industries. The hypothesis is tested using a non-parametric statistical test of two samples Kolmogorov-Smirnov Z.

\section{Hypothesis Two}

Hypothesis two examines the audit quality among specialist auditors in complex and noncomplex industries. Hypothesis two predict earnings quality of firms, measured by absolute abnormal accruals, with auditor industry specialists are greater in complex industries relative to those in less complex industries. The following is the model to test hypothesis two:

Ln_Abs_Akrual $t=B_{0}+B_{1}$ Industry $_{t}+B_{2}$ Lev $_{t}+B_{3}$ $\mathrm{ROA}_{\mathrm{t}}+64 \mathrm{Ln} \_\mathrm{Size}_{\mathrm{t}}+\mathrm{B}_{5} \mathrm{CFO}_{\mathrm{t}-1}+\varepsilon_{\mathrm{t}}$

Where,

Ln_Abs_Akrual $\mathrm{t}_{\mathrm{t}}=$ Absolute abnormal accruals are estimated separately using four different models and are transformed into natural logarithm; Industryt $=$ Dummy variable, 1 if the specialist auditor belong to complex industries and 0 otherwise; Lev $=$ Ratio of total debt to total assets; $\mathrm{ROA}_{\mathrm{t}}=$ Ratio of net income to total assets in year $\mathrm{t}$; Ln_Size $=$ The size of the firm that is transformed into natural logarithm; $\mathrm{CFO}_{\mathrm{t}}=$ Operating cash flow deflated by total assets

It should be noted that the abnormal accruals are transformed into absolute values to avoid negative and positive abnormal accruals cancel out. Such a situation may obscure the interpretation of the results. As discussed extensively in the accounting literature, negative abnormal accruals decrease reported earnings while positive abnormal accruals increase earnings. However, both are the result of manager discretion causing noises in reported earnings. Since this present study does not focus on the direction of abnormal accruals but the magnitude of abnormal accruals, absolute abnormal accruals are appropriate proxy for earnings quality. Absolute abnormal accruals are then transformed into natural logarithms because 
transforming abnormal accruals into absolute abnormal accruals causing data skewed to the right and potentially violate the assumption of normality. Transforming absolute abnormal accruals into natural logarithm follows Carcello et al. [49].

\section{Hypothesis Three}

Hypothesis three examines audit quality among non-specialist auditors incomplex and noncomplex industries. The following is the model to test hypothesis three:

Ln_Abs_Akrualt $=B_{0}+B_{1}$ Industryt $+B_{2} L e v t+B_{3}$ $\mathrm{ROA}_{\mathrm{t}}+B_{4} \mathrm{Ln}_{-}$Size $_{\mathrm{t}}+$ B $_{5} \mathrm{CFO}_{\mathrm{t}-1}+\varepsilon_{\mathrm{t}}$

Where,

Ln_Abs_Akrual $=$ Absolute abnormal accruals models estimated separately using four different models and are subsequently transformed into natural logarithms; Industryt $=$ Dummy variable, 1 if the non-specialist auditor belongs to complex industries and 0 otherwise; Levt $=$ Ratio of total debt to total assets; $\mathrm{ROA}_{\mathrm{t}}=$ Ratio of net income to total assets in year t; Size $_{i t}=\ln$ total asset; $\mathrm{CFO}_{\mathrm{t}}=$ Operating cash flow deflated by total assets.

\section{Results and Discussion}

\section{Descriptive Statistics}

There are 520 firm samples available during the 2012-2015 period. Table 2 reports descriptive statistics for variables related to auditor industry expertise and non-industry expertise. Panel A is descriptive statistics for firms using auditor industry specialization and panel B for non-industry specialization.

Table 2. Descriptive Statistics

Panel A: Specialist Auditor

\begin{tabular}{lcrrrr}
\hline \multicolumn{1}{c}{ Variable } & N & $\begin{array}{c}\text { Mini- } \\
\text { mum }\end{array}$ & $\begin{array}{c}\text { Maxi- } \\
\text { mum }\end{array}$ & Mean & Std.Dev \\
\hline Abs_Akrual & 288 & 0,000 & 0,687 & 0.074 & 0.082 \\
Industry & 288 & 0,000 & 1,000 & 0,240 & 0.430 \\
LEV & 288 & 0,000 & 2,460 & 0,541 & 0,368 \\
ROA & 288 & $-0,720$ & 0,490 & 0,061 & 0,101 \\
SIZE & 288 & 3,641 & 8,211 & 6,210 & 0,852 \\
CFO & 288 & $-0,610$ & 0,940 & 0,081 & 0,145 \\
\hline Panel B: Non-specialist auditor & & & \\
\hline Abs_Akrual & 232 & 0,000 & 0,351 & 0,063 & 0,058 \\
Industry & 232 & 0,000 & 1 & 0,410 & 0,492 \\
LEV & 232 & 0,000 & 1,460 & 0,476 & 0,270 \\
ROA & 232 & $-0,210$ & 2,05 & 0,103 & 0.174 \\
SIZE & 232 & 4,942 & 7,963 & 6.246 & 0.714 \\
CFO & 232 & $-1,840$ & 1,030 & 0.085 & 0.209 \\
\hline
\end{tabular}

Absolute abnormal accruals (Abs_Akrual) presented in table 2 are estimated using model introduced in Kothariet al. [45]. Panel A shows the mean for absolute abnormal accruals is $7.4 \%$ of total assets for firms in complex industries and $6.3 \%$ of the total asset for non-complex industries (panel B). Though two companies report high abnormal accruals of $68.7 \%$ and $35.1 \%$ respectively for each industry, on average earnings management level is quite moderate.

It can also be seen from Panel A and B, Industry has mean value of $24 \%$ and $41 \%$ respectively. They suggest that $24 \%$ of auditors who have industry expertise are hired by firms operating in complex industries, and $41 \%$ are employed by firms operating in non-complex industries. The statistics also show that the number of auditors who have industry expertise is lower than those who have no industry specialization. This is understandable because to gain adequate knowledge of a complex industry requires auditors to have a strong commitment to learning continually about the company's business activities. Not all auditors are willing to invest time and effort to understand complex industrial environments.

This study uses four control variables. They are LEV (debt level), ROA (profitability), SIZE (company size), and CFO (cash flow). On average, the firm samples in complex and non-complex industries have a reasonably safe level of debt that is below 1. This is reflected from a low debt ratio of 0.541 for the complex industries and 0.476 for noncomplex industries. Meanwhile, profitability is also quite moderate. The mean for ROA is 0.061 and 0.103 for complex and non-complex industries respectively. These figures suggest that on average, firms engaged in non-complex industries are more profitable than firms operating in complex industries. The firm is almost equal in size between the two industry groups. The same is true for the operating cash flow (CFO).

\section{RESULTS AND DISCUSSION}

Hypothesis One (H1) predicts a complex industrial environment causing firms' earnings to fluctuate sharply over the years resulting in lower earnings persistence. More specifically, H1 predicts earnings of firms operating in complex industries are less persistent than those in less complicated industries. Non-parametric statistical tests of two samples Kolmogorov-Smirnov Z are used to test the hypothesis. Kolmogorov-Smirnov $\mathrm{Z}$ is used because earnings persistence is not normally distributed.

The results described in Table 3 show that $\mathrm{Z}$ statistics of the two-sided test is equal to 1.284 and p-value of 0.074. However, conclusions are drawn using one-tailed test because the hypothesis is stated in a certain direction. It can thus be concluded that the earnings persistence (Asymp 0.074 
/ $2=0.037)$ in the complex industries is lower than that of less complex industries. The results support the industry grouping proposed by Francis and Gunn [2].

Table 3. Differences in Persistence of Complex Profit Industry and Less Complex

\begin{tabular}{lc}
\hline & Earnings Persistent \\
\hline Kolmogorov-Smirnov Z & 1,284 \\
Asymp. Sig. (Two-tailed) &, 074 \\
\hline
\end{tabular}

Firms engaged in complex business environments are more volatile because earnings measurement is more difficult and contains higher measurement errors than other companies operating in less complex industries. Danos [33] stated that the accounting complexity in specific industry requires accountants to have particular accounting knowledge to identify potential problems in clients' financial statements

Hypothesis Two (H2) indicates that the knowledge of specialist auditors become less relevant in complex industries. Therefore it is predicted that absolute abnormal accruals of firms operating in complex industrial environments are expected to be higher than firms operating in less complex environments. The firms used to test $\mathrm{H} 2$ are limited to those audited by industry specialist auditor. As a consequence, Only 149 firm samples are available to test H2. Moreover, as much as 13 firm samples must be eliminated to meet normality assumption underlying multiple regression analysis. The final firm samples to test $\mathrm{H} 2$ is 136 observations. Table 4 summarizes the effect of industry complexity and specialist auditors on abnormal absolute accruals.

It should be noted that the abnormal accruals shown in table 4 are estimated using performancematched discretionary accruals model introduced in Kothari et al. [45]. Inferences are drawn based on this model. The analysis focuses on industry variable which is a dummy variable that takes one if firms operating in a complex industry and 0 otherwise. Table 4 shows the coefficient has a positive value and statistically significant at less than $1 \%$. Positive directions indicate that the abnormal accruals of firms in the complex industries are higher than those of the less complex industries although both use industry specialization auditors. Hence, $\mathrm{H} 2$ is supported statistically.

Overall, the findings suggest the auditor's industry expertise does not play a significant role in complex industries. The uncertain business environment makes it difficult for auditors to assess whether the accounting policies used by the company conform with accepted accounting standards. Moreover, the findings explain the inconsistent results reported by various studies in Indo- nesia $[14,15,16,17,18,19,20,21,22,2324,25]$. As described earlier, some studies reported a positive association between industry specialist auditors and audit quality but some found a negative association. The result of the present research shows that industry complexity must be controlled to assess the effect of auditor industry expertise on audit quality.

We perform further analysis to test the validity of the results. Sensitivity analysis is performed by re-estimating abnormal accruals using three different models that have been described earlier. Table 5 reports that the coefficients for Industry in all models have the positive direction. The results are consistent with evidence reported in table 4 . However, the significance level of the three models varies, ranging from $1 \%$ for modified Jones, $5 \%$ for Ball and Shivakumar model, and 10\% for Kasznik model. Overall these results suggest that industry complexity cause the adverse effect on the quality of audited earnings.

The industry complexity is predicted to not only decreases the ability of specialist auditors to assess and verify client's accounting policies but also the ability of non-specialist auditors. The relationship between industry complexity and nonspecialist auditors is stated in hypothesis three (H3). Hypothesis three emphasizes the pronounced effect of industry complexity on non-specialist auditors relative to specialist auditors in maintaining the quality of financial statements.

Table 4. Abnormal Accruals and Auditor Industry Expertise In Complex Industry

Model: $L n \_A b s \_A k r u a l_{t}=\gamma_{0}+\gamma_{1}$ Industry $_{t}+\gamma_{2} L n \_S I Z E_{t}+$ $\gamma_{3} D A R_{t}+\gamma_{4} R O A_{t}+\gamma_{5} C F O_{t}+\varepsilon_{t}$

\begin{tabular}{lccccc}
\hline Variables & $\begin{array}{c}\text { Predicted } \\
\text { Signs }\end{array}$ & $\begin{array}{c}\text { Coefficie } \\
\text { nts }\end{array}$ & $\begin{array}{c}\text { Std. } \\
\text { Error }\end{array}$ & $\begin{array}{c}\text { t-statis- } \\
\text { tics }\end{array}$ & P-Value \\
\hline Industry & $(+)$ & 0,373 & 0,124 & 3,007 & 0,003 \\
Ln_Size & $(+)$ & $-0,044$ & 0,037 & $-1,172$ & 0,243 \\
DAR & $(+)$ & 0,415 & 0,263 & 1,577 & 0,117 \\
ROA & $(+)$ & 0,249 & 0,884 & 0,282 & 0,779 \\
CFO & $(+/-)$ & 0,738 & 0,662 & 1,115 & 0,267 \\
\hline N & & 135 & & & \\
Adjusted $R^{2}$ & & 0,06 & & & \\
\hline
\end{tabular}

Table 5. Abnormal Accruals and Auditor Industry Expertise in Complex Industry (Alternative Models)

Ln_Abs_Akrual ${ }_{t}=\gamma_{0}+\gamma_{1}$ Industry $_{t}+\gamma_{2} \operatorname{Ln} \_$SIZE $_{t}+\gamma_{3} \mathrm{DAR}_{\mathrm{t}}$ $+\gamma_{4} \mathrm{ROA}_{\mathrm{t}}+\gamma_{5} \mathrm{CFO}_{\mathrm{t}}+\varepsilon_{\mathrm{t}}$

\begin{tabular}{|c|c|c|c|c|c|c|}
\hline & \multicolumn{2}{|c|}{$\begin{array}{c}\text { Ball dan } \\
\text { Shivakumar } \\
\text { Model }\end{array}$} & \multicolumn{2}{|c|}{$\begin{array}{l}\text { Modified Jones } \\
\text { Model }\end{array}$} & \multicolumn{2}{|c|}{ Kasznik Model } \\
\hline & Coef. B & -value & Coef. B & value & Coef. B & -value \\
\hline Industry & 0,272 & 0,033 & 0,392 & 0,002 & 0,248 & 0,087 \\
\hline Ln_Size & $-0,037$ & 0,313 & $-0,025$ & 0,487 & 0,011 & 0,784 \\
\hline DAR & 1,270 & 0,000 & 0,386 & 0,145 & 0,026 & 0,931 \\
\hline ROA & 2,387 & 0,012 & 1,340 & 0.132 & 0,543 & 0,593 \\
\hline $\mathrm{CFO}$ & 0,009 & 0,989 & $-0,206$ & 0,745 & 0,617 & 0,395 \\
\hline $\mathrm{N}$ & 132 & & 144 & & & 140 \\
\hline Adj. R2 & 0,190 & & 0,054 & & & 0,012 \\
\hline
\end{tabular}


Table 6 presents the impact of industry complexity on financial statements audited by nonspecialist auditors. It should be noted that the samples used to test $\mathrm{H} 3$ are limited to firms who hire non-specialist auditors. As a consequence, firm samples available to conduct regression analysis is down to 267 observations. As much as 31 firm samples were eliminated, leaving only 236 firm samples to test H3. The results are shown in Table 6 . The focus is on variable Industry which is a dummy variable that takes one if the firm operates in a complex industry and 0 otherwise.

As seen in table 6, Industry has positive sign with a p-value of 0,045. Therefore, H3 is statistically supported with the significant level at $5 \%$. The results suggest that the absolute abnormal accruals of firms in complex industries are higher relative to firms operating in less complex industries even though they use non-specialist auditors. The results support previous findings that industry complexity hurts the quality of financial statements.

Robustness check is also conducted to assess whether the results are specific or dependent upon the model used. Table 7 summarizes the results using three alternative models.

Table 6. Non-spesialist Auditors In Complex and Noncomplex Industry

Ln_Abs_Akrual ${ }_{t}=\gamma_{0}+\gamma_{1}$ Industry $_{\mathrm{t}}+\gamma_{2} \operatorname{Ln} \_\mathrm{SIZE}_{\mathrm{t}}+\gamma_{3} \mathrm{DAR}_{\mathrm{t}}$ $+\gamma_{4} \mathrm{ROA}_{\mathrm{t}}+\gamma_{5} \mathrm{CFO}_{\mathrm{t}}+\varepsilon \mathrm{t}$

\begin{tabular}{lcrrrr}
\hline Variables & $\begin{array}{c}\text { Predicted } \\
\text { signs }\end{array}$ & $\begin{array}{c}\text { Coeffi- } \\
\text { cients }\end{array}$ & $\begin{array}{c}\text { Std. } \\
\text { Error }\end{array}$ & $\begin{array}{c}\text { t- } \\
\text { statistics }\end{array}$ & $\begin{array}{c}\text { P- } \\
\text { Value }\end{array}$ \\
\hline Industry & $(+)$ & 0,205 & 0,101 & 2,017 & 0,045 \\
Ln_Size & $(+)$ & $-0,009$ & 0,030 & $--0,312$ & 0,755 \\
DAR & $(+)$ & 0,402 & 0,148 & 2,717 & 0,007 \\
ROA & $(+)$ & $-0,763$ & 0,524 & $-1,456$ & 0,147 \\
CFO & $(+/-)$ & 3,397 & 0,540 & 6,293 & 0,000 \\
\hline N & & 135 & & & \\
Adjusted $R^{2}$ & & 0,17 & & & \\
\hline
\end{tabular}

Table 7. Non-specialist Auditors In Complex and NonComplex Industry (Alternative Models)

Ln_Abs_Akrual $=\gamma_{0}+\gamma_{1}$ Industryt $_{\mathrm{t}}+\gamma_{2} \mathrm{Ln}_{-} \mathrm{SIZE}_{\mathrm{t}}+\gamma_{3} \mathrm{DAR}_{\mathrm{t}}$ $+\gamma_{4} \mathrm{ROA}_{\mathrm{t}}+\gamma_{5} \mathrm{CFO}_{\mathrm{t}}+\varepsilon \mathrm{t}$

\begin{tabular}{lrrrrrr}
\hline \multicolumn{4}{c}{$\begin{array}{c}\text { Ball dan } \\
\text { Shivakumar } \\
\text { Model }\end{array}$} & \multicolumn{3}{c}{$\begin{array}{c}\text { Modified Jones } \\
\text { Model }\end{array}$} \\
& \multicolumn{3}{c}{ Coef. B $p$-value } & Coef. B $p$-value & Coef. B $p$-value \\
\hline Industry & 0,051 & 0,708 & 0,216 & 0,091 & 0,400 & 0,001 \\
Ln_Size & $-0,093$ & 0,017 & $-0,042$ & 0,254 & $-0,090$ & 0,011 \\
DAR & 0,874 & 0,000 & 0,467 & 0,002 & 0,435 & 0,001 \\
ROA & $-0,178$ & 0,788 & 0,300 & 0.636 & $-0,095$ & 0,872 \\
CFO & 0,083 & 0,871 & $-0,535$ & 0,277 & 0,126 & 0,804 \\
\hline N & 243 & 5 & 256 & & & 243 \\
Adj. R2 & 0,104 & & 0,042 & & 0,089 \\
\hline
\end{tabular}

Of the three models, only the Ball and Shivakumar model fail to detect differences in absolute abnormal accrualsof firms with non-specialist auditors in complex and non-complex industries. Kasznik and modified Jones models support previous findings with a significance level of less than $1 \%$ and at $10 \%$.

\section{CONCLUSIONS, LIMITATIONS, AND SUGGESTIONS}

\section{Conclusions}

The assumption that the auditors who have industry specialization expertise can always improve the quality of financial statements regardless of type of industries they operate are misleading. The complexity of industry may reduce or even eliminate the effect of auditor industry expertise. Knowledge of business practices and norms in particular industry are often unique and useful only in less complex industry. This study examines the importance of auditor industry expertise in improving the quality of financial statements by taking into account industry complexity.The findings are summed up as follows:

1. Earnings Persistence of firms in complex industries is lower than firms in non- complex industry.

2. Auditor industry expertise does not affect financial statements quality of firms operating in complex business environments. The result suggests that investors should consider industry complexity before making investment decisions. Hiring public accounting firms who have industry expertise are only appropriate for firms engaged in less complex industries. The specialist auditor alone is not enough to guarantee that the financial statements have reasonably reflected economics reality and firm prospects in the future.

3. Absolute abnormal accruals of firms operating in complex industries are higher relative to those in-non complex industries despite the fact that they hire non-specialized industry auditors.

Several prior studies in Indonesia have shown industry-specific auditors play an important role in improving the quality of financial statements. But results of this present study suggest that the knowledge of business practices in an industry does not improve the ability of auditors in enhancing financial reporting quality of firms in complex business environments. Moreover, the significant effect of industry complexity on the quality of financial statements identified in this 
study may explain the inconsistent results of previous auditor industry specialization studies in Indonesia.

\section{Limitations}

The data used in this study come from publicly available sources. Unfortunately annual reports of firm samples are not all available online during the sample period of 2012-2015. This might affect the results. Therefore, inferential should be taken cautiously in the context of firms sample and periods.

The procedure to separate firms into a complex and non-complex industry based on Jakarta Stock Industrial Classification could be too broad and fail to distinguish different environment dynamics. Incorrect grouping might have affected the results reported in this study.

\section{Suggestions}

Following are two suggestions for future research (1) Use different proxy for earnings quality such as earnings response coefficients, stock prices synchronicity and earnings timeliness, and (2) Subsequent research may consider the classification of complexity by sub-industry.

\section{REFERENCES}

[1] Bushman, R., Q. Chen, E. Engel, and A. Smith. (2004). Financial accounting information, organizational complexity, and corporate governance systems, Journal of Accounting andEconomics 37: 167-201.

[2] Francis, J.R., and J. L., Gunn. (2015), Industry accounting complexity and earnings properties: does auditor industry expertise matters?, Working Paper, University of Missouri and the University of Pittsburgh.

[3] Doyle, J., W. Ge, and S. McVay. (2007). Determinants of weaknesses in internal control over financial reporting, Journal of Accounting and Economics 44: 193-223.

[4] Plumlee, M., and T. Yohn. (2010), An analysis of the underlying causes attributed to restatements, Accounting Horizons 24 (1): 41-64.

[5] Dunn, K. A., and B. W. Mayhew. (2004), Audit Firm Industry Specialization and Client disclosure quality, Working paper, Florida Atlantic University and the University of Wiscon$\sin$.

[6] Dechow, P., and I. Dichev. (2002), The quality of accruals and earnings: the role of accrual estimation errors, The Accounting Review 77: 35-59.
[7] Balsam, S., J. Krishnan, and J. S. Yang. (2003), Auditor industry specialization and earnings quality, Auditing: A Journal of Practice \& Theory 22: 71-97.

[8] Cahan, S., J. Godfrey, J. Hamilton, and D. Jeter. (2008). Auditor specialization, auditor dominance, and audit fees: the role of investment opportunities. The Accounting Review 83 (6): 1393-1423..

[9] Craswell, A., J. Francis, and S. Taylor. (1995), Auditor brand name reputation and industry specialization, Journal of Accounting and Economics 20: 297-322.

[10] Hogan, C. E., and D. C. Jeter. (1999), Industry specialization by auditors, Auditing: A Journal of Practice \&Theory 18: 1-17.

[11] Ferguson, A., J.R. Francis., and Stokes. (2003), The effects of firm-wide and office -level industry expertise on audit pricing, The Accounting Review 78 (2): 429-448.

[12] Choi, J.-H., J.B. Kim, A. Qiu, and Y. Zang. (2012), Geographic proximity between auditor and client: how does it impact audit quality?, Auditing: A Journal of Practice and Theory 31 (2): 43-72.

[13] Reichelt, K., and D. Wang. (2010), National and office-specific measures of auditor industry-expertize effects on audit quality, Journal of Accounting Research 48 (3): 647-686.

[14] Setiawan, L.W., dan Fitriany. (2011), Pengaruh workload dan spesialisasi auditor terhadap kualitas audit dengan kualitas komite audit sebagai variabel pemoderasi. Jurnal Akuntansi Keuangan Indonesia 8: 36-53.

[15] Rahadianto, N.A. (2012). Analisis pengaruh auditor spesialis industri, Dewan Komisaris, Komite Audit, dan penerapan PSAK 50/55 (revisi 2006) terhadap audit delay pada industri perbankan. Skripsi yang tidak dipublikasikan. Universitas Indonesia.

[16] Senjaya, K., dan B. Suprasto. (2013), Tingkat spesialisasi industri auditor sebagai pemoderasi pengaruh ukuran perusahaan pada audit delay, E-Jurnal Akuntansi, Universitas Udayana.

[17] Nugrahanti, Y. (2014), Pengaruh audit tenure, spesialisasi kantor akuntan publik, dan ukuran perusahaan terhadap kualitas audit, Skripsi yang tidak dipublikasikan, Universitas Diponegoro.

[18] Fitriany, S. Utama, D. Martani, H. Rosietta. (2015), Pengaruh tenur, rotasi, dan spesialisasi Kantor Akuntan Publik (KAP) terhadap kualitas audit: perbandingan sebelum dan sesudah regulasi rotasi KAP di Indonesia, Jurnal Akuntansi dan Keuangan 17 (1): 1227. 
[19] Kusuma, R. W. R dan D.T.H. Manurung. (2016), Pengaruh kualitas audit, tenur audit terhadap audit report lag dengan spesialisasi industri auditor sebagai variabel moderasi, Working paper, Universitas Widyatama, Bandung.

[20] Novianti, Sutrisno, dan G. Irianto. (2012), Tenur kantor akuntan publik, Tenur Partner Audit, Auditor spesialisasi industri, dan kualitas audit, Paper dipresentasikan pada Simposium Nasional Akuntansi XV, Universitas Lambung Mangkurat, Banjarmasin, 20-23 September 2012.

[21] Herusetya, A. (2009), Pengaruh ukuran auditor, dan spesialisasi auditor terhadap kualitas laba. Jurnal Akuntansi dan Keuangan Indonesia 6 (1): 46-70.

[22] Chrisnoventie, D. (2012), Pengaruh ukuran KAP dan spesialisasi industri KAP terhadap kualitas audit: tingkat risiko litigasi perusahaan sebagai variabel moderasi, Skripsi yang tidak dipublikasikan, Universitas Diponegoro.

[23] Wintono, S. D. (2014). Pengaruh tenur audit dan spesialisasi KAP terhadap kualitas audit dengan reputasi KAP sebagai variabel pemoderasi, Skripsi tidak dipublikasi, Universitas Sebelas Mare.

[24] Suresti, A. (2015), Pengaruh workload, auditor spesialisasi industri, dan audit tenure terhadap kualitas audit dengan komite audit sebagai variabel moderating, Skripsi tidak dipublikasi, Universitas Islam Negeri Syarif Hidayatullah Jakarta.

[25] Pertiwi, N.P., A. Hasan., dan Hardi. (2016). Pengaruh masa perikatan audit, spesialisasi industri KAP, reputasi KAP,dan Komite Audit terhadap kualitas audit. Jurnal Akuntansi 4 (2): 147-160.

[26] Duru, A., Reeb, D., (2002), Geographic and industrial corporate diversification: the level and structure of executive compensation, Journal of Accounting Auditing and Finance 17, 1-24.

[27] Denis, D.J., Denis, D.K., Yost, K. (2002), Global diversification, industrial diversification, and firm value, Journal of Finance 57, 1951-1980.

[28] Bodnar, G., Tang, C., Weintrop, J. (1998), Both sides of corporate diversification: the value impacts of geographic and industrial diversification, Working Paper, Wharton School

[29] Owen, A.L., and C. Polk. (2000), Does diversification destroy value? Evidence from industry shocks, Journal of Financial Economics 63: 51-77.

[30] Gilson, S., Healy, P., Noe, C., Palepu, K. (2001), Analyst specialization and conglome- rate breakups, Journal of Accounting Research 39, 565-582

[31] Givoly, D., Hayn, C., D'Souza, J. (1999), Measurement errors and information content of segment reporting, Review of Accounting Studies 4(1), 15-43.

[32] Peterson, K. (2012), Accounting complexity and misreporting and the consequences of misreporting, Review of Accounting Studies 17: 72-95.

[33] Danos, P., W. Eichenseher, and D. Holt. (1989), Specialized knowledge and its communication in auditing, Contemporary Accounting Research 6(1): 91-109.

[34] Porter, M.E. (1985), The competitive advantage: Creating and sustaining superior performance, NY: Free Press.

[35] Mayhew, B. W., and M. S. Wilkins. (2003), Audit firm industry specialization as a differentiation strategy: Evidence from fees charged to firms going public, Auditing: $A$ Journal of Theory \& Practice 22: 33-52.

[36] Chan, D. K., A. Ferguson, D. A. Simunic, and D. Stokes. (2001), A spatial analysis and test of oligopolistic competition in the market for assurance services, Working paper, University of British Columbia.

[37] Dichev, L.D., J.R. Graham., C.R. Harvey, and S. Rajgopal. (2013), Earnings quality: Evidence from the field, Journal of Accounting and Economics 56: 1-33.

[38] Ferguson, A., and D. Stokes. (2002), Brand name audit pricing, industry specialization and industry leadership premiums post-Big 8 and Big 6 mergers, contemporary accounting Research 19: 77-110..

[39] Simunic, D., and M. Stein. (1987), Product Differentiation in Auditing: Auditor Choice in The Market for Unseasoned New Issues, Vancouver, Canada: Canadian Certified General Accountants' ResearchFoundation.

[40] Khrisnan, J. and Yang, J.S. (1999), Auditor industry specialization and Earnings Response Coefficient, Working paper, Temple University.

[41] Carcello, J., and A. L. Nagy. (2002), Auditor industry specialization and fraudulent financial reporting, Proceedings of the 2002 Deloitte and Touche/University of Kansas Symposium on Auditing Problems.

[42] Kwon, S.Y., C. Y. Lim., and P.M.S. Tan. (2007), Legal systems and earnings quality: The role of auditor industry specialization, Auditing: A Journal of Practice \& Theory 26(2): 25-55.

[43] Krishnan, J. (2003), Does Big 6 auditor industry expertise constraint earnings manage- 
ment?, Accounting Horizons (supplement) 116.

[44] Sloan, R. (1996), Do stock prices fully reflect information in accruals and cash flows about future earnings? The Accounting Review 71 (3): 289-315.

[45] Kothari, S.P., J. Leone, and C. Wasley. (2005), Performance matched discretionary accruals measures, Journal of Accounting and Economics 39: 163-197.

[46] Ball, R., Shivakumar, L., (2006), Earnings quality in UK private firms: comparative loss recognition timeliness, Journal of Accounting and Economics 39, 83-128.
[47] Dechow, P., Sloan, R., Sweeney, A., (1995), Detecting earnings management. The Accounting Review 70, 193-225.

[48] Kasznik, R., (1999), On the association between voluntary disclosure and earnings management, Journal of Accounting Research 37, 57-81.

[49] Carcello, J., C.W. Hollingsworth., A. Klein., and T. L. Neal. (2007), Audit committee financial expertise, competing for corporate governance mechanism, and earnings management in a Post-Sox World, Working paper, University of Tennessee, Clemson University and New York University.

\section{List of Industries}

\begin{tabular}{ll}
\hline Complex Industries & Non-Complex Industries \\
\hline Agriculture & Food Products \\
Entertainment & Candy \& Soda \\
Healthcare & Beer \& Liquor \\
Construction & Recreation \\
Defense & Printing and Publishing \\
Precious Metals & Consumer Goods \\
Non-metallic and Industrial Metal Mining & Apparel \\
Coal & Medical Equipment \\
Petroleum and Natural Gas & Pharmaceutical Products \\
Utilities & Chemicals \\
Communication & Rubber and Plastic Products \\
Business Services & Textiles \\
Computers & Construction Materials \\
Transportation & Steelworks, etc. \\
Banking & Fabricated Products \\
Insurance & Machinery \\
Real Estate & Electrical Equipment \\
Trading & Automobiles and Trucks \\
& Aircraft \\
& Shipbuilding, Railroad Equipment \\
& Personal Services \\
& Electronic Equipment \\
& Measuring and Control Equipment \\
& Business Supplies \\
& Shipping Containers \\
& Wholesale \\
& Retail \\
& Restaurants, Hotels, Motels \\
& Food Products \\
\hline
\end{tabular}

